\title{
REPRODUCTIVE EFFORT AS AN ELEMENT OF LIFE STRATEGY OF LYTHRUM SALICARIA L. POPULATIONS
}

\author{
Bożenna Czarnecka, Magdalena Franczak, Katarzyna Nowak \\ Department of Ecology, Maria Curie-Skłodowska University in Lublin, Poland \\ e-mail: boczar@biotop.umcs.lublin.pl; mpelc@biotop.umcs.lublin.pl
}

Received: 22.10 .2007

S u m m a r y

The aim of the study was to compare some life strategy traits of individuals of Purple Loosestrife Lythrum salicaria within three meadow populations existing under various habitat conditions. The study attempted to answer the following questions: Do different habitat conditions affect the biomass allocation between particular organs of individuals? Can the individuals belonging to different populations of the same species realise their own unique reproductive strategy, in other words, can their reproductive effort represent various levels? In the case of $L$. salicaria the reproductive effort, measured by the participation of inflorescence biomass in the biomass of aboveground parts of genets, exhibits similar values (14.2-15.1\%) in all the study populations, despite their habitat conditions. This fact proves that at the population level, the reproductive effort is relatively stable. Great differences are visible in the case of particular individuals within each of the populations. Specific genets in a population, depending on the habitat microstructure and the biotic relations with other individuals both of their own and other species, may realise their own reproductive strategies, being a part of their life strategies.

Key words: reproductive effort, biomass allocation, life strategy, trade-off, clonal plant, Lythrum salicaria

\section{INTRODUCTION}

Life history of a species, also referred to as its lifestyle, comprises the entire course of events in the life of an individual (genet) connected with successive stages of its development and growth, until its death (H a r p e r, 1977). The genet survival in a population, affected by a set of unique habitat conditions, is determined by a set of life history traits. Temporal pattern of its growth and reproduction is shaped by such features as, among others, growth rate, size, body mass, vegetative offspring and number of generative propagules produced per one generative episode, and the number of such episodes during the ontogeny (S t e a r n s, 1992). Each individual is affected by a different selection force, resulting from natural selection, both under the influence of habitat conditions, which change with different rate, and under the pressure of intra- and interspecific competition. These limitations condition the shaping of such a combination of life history traits which becomes a life strategy. At the level of an individual, a web of evolutionary trade-offs is formed, which is a result of the drive to reach maximum size and reproduction success on the one hand, and to adapt to the environment and last in time on the other ( $\mathrm{S}$ i l ve r tow n and L ovet t Dous t, 1993; C r aw le y, 1997).

In clonal species of the iterative growth type which multiply their basic structures, i.e. shoots, rhizomes and roots, and thus expand the genet, a particularly important element of life strategy is the biomass allocation to vegetative and generative parts of plants. The part of the biomass (energy) used to produce generative organs, in relation to the total biomass (energy) of an individual, is defined as reproductive effort ( $\mathrm{H}$ a r p e $\mathrm{r}$ and $\mathrm{Ogden}, 1970)$.

The aim of the present study is to compare some life strategy traits of individuals of Purple Loosestrife Lythrum salicaria within three populations existing in different types of meadow vegetation occurring in habitats of various resource abundance. The study attempts to answer the following questions: Do different habitat conditions affect the division of energy between particular organs of individuals? Can the individuals belonging to different populations of the same species realise their own unique reproductive strategy, in other words, can their reproductive effort represent various levels?

\section{MATERIALS AND METHODS}

The study was carried out in the Szum river valley in the Central (Tomaszów) Roztocze region, near 
Górecko Kościelne. The study area comprised hydrogenic habitats, within the inundation terrace and occupied by communities of variously moist meadows of the Molinio-Arrhenatheretea class. Their vegetation was dominated, first of all, by macroforbes: Filipendula ulmaria, Lythrum salicaria, Lysimachia vulgaris, Cirsium rivulare, C. oleraceum.

Purple Loosestrife Lythrum salicaria L. (Lythraceae) is a perennial clonal plant belonging to rhizocaulophytes ( $\mathrm{L} \mathrm{u} \mathrm{k} \mathrm{a} \mathrm{s} \mathrm{i} \mathrm{e} \mathrm{w} \mathrm{i} \mathrm{c} \mathrm{z} \mathrm{,} \mathrm{1962).} \mathrm{Genets} \mathrm{of} \mathrm{L.} \mathrm{salicaria}$ are compact and usually consist of several, maximum a dozen, of ramets. Therefore, the species takes part in the formation of both fine-grained and coarse-grained spatial mosaic. The calendar age of genets is estimated as exceeding 10 years. Strong, well-shaped underground organs enable the individuals to last long in the once occupied area. Therefore, L. salicaria realises its dynamics in time rather than in space, and belongs to the promoters of succession within meadow communities (F a li ń s k a , 1991, 2003).

In order to conduct the biometrical analysis and to estimate the biomass, the total number of 90 generative individuals of $L$. salicaria were collected in the growing season of the year 2006. The genets came from three meadow patches (30 plants out of each), differing in habitat conditions, vegetation composition and population density. The patches of Cirsietum rivularis (A) and Lythro-Filipenduletum ulmariae (B) occupy eutrophic habitats on a flat inundation terrace, supplied with highly mineralised waters (300-350 $\left.\mathrm{mg} \mathrm{dm}^{-3}\right)$. The vegetation of the third of the analysed patches, Lysimachio vulgaris-Filipenduletum (C), occupies poorer soils, supplied with acidic, lowly mineralised (100-130

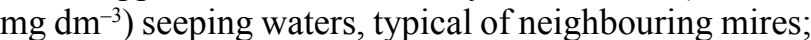
it is characteristic of a high participation of Carex acutiformis, too. Population density of L. salicaria in particular patches was as follows: patch $\mathrm{A}-1.00$ genet $\mathrm{m}^{-2}$, patch $\mathrm{B}-4.25$ genets $\mathrm{m}^{-2}$, and patch $\mathrm{C}-3.05$ genets $\mathrm{m}^{-2}$. Measurement comprised the following morphological features: stem height (1 $\mathrm{cm}$ accuracy), number of branches, leaves and inflorescences, and inflorescence length $(0.5 \mathrm{~cm}$ accuracy). Aboveground parts of plants were subsequently divided into the stem, leaves and the inflorescence part. The material thus divided was dried and weighed with the $0.0001 \mathrm{~g}$ accuracy. In order to determine the reproductive effort, the participation of inflorescence biomass in the total biomass of an individual's aboveground parts was measured. The results were analysed statistically with the Shapiro-Wilk, Levene and Kruskal-Wallis tests.

\section{RESULTS}

The differences between the study populations of Lythrum salicaria were significant $(0.001<\mathrm{p}<0.05)$ in case of all the features subjected to biometrical analy- sis. Most of them do not exhibit the Gaussian distribution, with the exception of stem height (all populations), number of shoot branches (patch A, i.e. Cirsietum rivularis population), and leaves (patch $\mathrm{A}$ and patch $\mathrm{B}$ - Lythro-Filipenduletum ulmariae). Genets from patch $\mathrm{B}$ are characteristic of the lowest mean height of ramets, while all the remaining analysed vegetative parameters reach their highest values here (Tab. 1). The average number of leaves per individual is twice as high as in the case of patch $\mathrm{C}$ (Lysimachio vulgaris-Filipenduletum population). As far as the generative features are concerned, individuals from patch $B$ have shown the highest number of inflorescences (Tab. 2, Fig. 1). In all the populations, the inflorescence length is negatively correlated with their number; patch $\mathrm{A}: \mathrm{r}=-0.33$; patch B: $r=-0.10$; patch $C: r=-0.29$. The genets of $L$. salicaria occupying patch A exhibit the intermediate values of all the parameters in respect to the remaining populations. The only exception is the average inflorescence length which reaches its lowest value in this population. The lowest variability among all the analysed features was observed in patch B.

The comparison of the aboveground parts of plants additionally indicates the biggest size of genets in patch B (statistically significant differences between the populations), and the smallest size in patch $\mathrm{C}$ (Fig. 2). The average percentage of biomass coming from particular aboveground parts of plants was similar in all the populations and was contained within the following ranges: stem $49.8-52.1 \%$, leaves $-33-36 \%$ and inflorescence $-14.2-$ $15.1 \%$. The individuals of $L$. salicaria coming from the $\mathrm{C}$ population exhibit the lowest value of the coefficient of variation in the case of the stem and inflorescence biomass (Tab. 3). The greatest variability in the biomass allocation was observed for the individuals of the A population. The reproductive effort of the $\mathrm{B}$ and $\mathrm{C}$ populations showed similar values (15.1 and $14.9 \%$ ), while its slightly smaller value $(14.2 \%)$ was noted in the population coming from the Cirsietum rivularis patch (Tab. 4). Great differences are visible in particular individuals within each of the populations; population A: 8-times different, population B: ca. 4-times, population C: ca 3-times.

\section{DISCUSSION}

One of the most important evolutionary tradeoffs undertaken by clonal species is the share of biomass spent on vegetative growth and generative reproduction. In the case of Lythrum salicaria, habitat differences are reflected in the diverse size and genet architecture in particular populations, which further influence the biomass of an individual and its reproductive effort. Purple Loosestrife occurs in the patch of macroforbes LythroFilipenduletum ulmariae (patch B), where the individuals are frequently branched, and therefore producing the highest number of inflorescences. Despite its highest 
Table 1

Vegetative traits of individuals in the Lythrum salicaria populations.

\begin{tabular}{|c|c|c|c|c|c|c|c|c|c|c|c|c|}
\hline \multirow{2}{*}{ Patch } & \multicolumn{4}{|c|}{ Stem height $[\mathrm{cm}]$} & \multicolumn{4}{|c|}{ Number of shoot branches } & \multicolumn{4}{|c|}{ Number of leaves } \\
\hline & $\bar{x} \pm \mathrm{SD}$ & Sk & K & $\mathrm{V}[\%]$ & $\bar{x} \pm \mathrm{SD}$ & Sk & K & $\mathrm{V}[\%]$ & $\bar{x} \pm \mathrm{SD}$ & Sk & $\mathrm{K}$ & $\mathrm{V}[\%]$ \\
\hline A & $98.2 \pm 16.6$ & -0.19 & 0.40 & 16.90 & $6.7 \pm 3.3$ & 0.31 & -0.09 & 49.25 & $195.5 \pm 79.8$ & 0.14 & -0.46 & 40.82 \\
\hline B & $93.3 \pm 13.2$ & 0.33 & 0.51 & 14.15 & $8.7 \pm 4.9$ & 0.39 & -0.59 & 56.32 & $297.9 \pm 100.8$ & 0.41 & -0.60 & 33.84 \\
\hline $\mathrm{C}$ & $104.8 \pm 15.5$ & -0.10 & -0.52 & 14.79 & $6.2 \pm 5.1$ & 0.51 & -0.89 & 82.26 & $127.1 \pm 55.6$ & 1.32 & 1.87 & 43.74 \\
\hline
\end{tabular}

$\bar{x}$ - arithmetic mean, $\mathrm{SD}$ - standard deviation, $\mathrm{Sk}$ - skewness, $\mathrm{K}$ - kurtosis, $\mathrm{V}$ - coefficient of variation

Table 2

Generative traits of individuals in the Lythrum salicaria populations.

\begin{tabular}{|c|c|c|c|c|c|c|c|c|}
\hline \multirow{2}{*}{ Patch } & \multicolumn{4}{|c|}{ Number of inflorescences } & \multicolumn{4}{c|}{ Inflorescence length [cm] } \\
\cline { 2 - 9 } & $\bar{x} \pm \mathrm{SD}$ & $\mathrm{Sk}$ & $\mathrm{K}$ & $\mathrm{V}[\%]$ & $\bar{x} \pm \mathrm{SD}$ & $\mathrm{Sk}$ & $\mathrm{K}$ & $\mathrm{V}[\%]$ \\
\hline $\mathrm{A}$ & $11.6 \pm 8.6$ & 1.53 & 3.27 & 74.14 & $5.3 \pm 2.2$ & 2.08 & 4.92 & 41.51 \\
\hline $\mathrm{B}$ & $17.6 \pm 8.6$ & 1.97 & 5.84 & 48.86 & $6.2 \pm 2.0$ & 1.00 & 1.06 & 32.26 \\
\hline $\mathrm{C}$ & $8.1 \pm 5.3$ & 0.84 & 0.54 & 65.43 & $9.2 \pm 4.2$ & 0.57 & 0.03 & 45.65 \\
\hline
\end{tabular}

Table 3

Biomass allocation in generative individuals of Lythrum salicaria populations (in g).

\begin{tabular}{|c|c|c|c|c|c|c|c|c|c|c|c|c|}
\hline \multirow{2}{*}{ Patch } & \multicolumn{4}{|c|}{ Stem biomass } & \multicolumn{4}{c|}{ Leaf biomass } & \multicolumn{4}{c|}{ Inflorescence biomass } \\
\cline { 2 - 13 } & $\bar{x} \pm \mathrm{SD}$ & $\mathrm{Sk}$ & $\mathrm{K}$ & $\mathrm{V}[\%]$ & $\bar{x} \pm \mathrm{SD}$ & $\mathrm{Sk}$ & $\mathrm{K}$ & $\mathrm{V}[\%]$ & $\bar{x} \pm \mathrm{SD}$ & $\mathrm{Sk}$ & $\mathrm{K}$ & $\mathrm{V}[\%]$ \\
\hline $\mathrm{A}$ & $4.78 \pm 3.36$ & 1.59 & 2.41 & 70.29 & $3.22 \pm 1.71$ & 1.07 & 1.13 & 53.10 & $1.27 \pm 0.96$ & 2.40 & 8.17 & 75.59 \\
\hline $\mathrm{B}$ & $6.49 \pm 3.66$ & 2.94 & 11.24 & 56.39 & $3.94 \pm 1.53$ & 0.61 & -0.26 & 38.83 & $1.94 \pm 1.32$ & 2.12 & 5.96 & 68.04 \\
\hline $\mathrm{C}$ & $3.97 \pm 2.05$ & 1.25 & 1.09 & 51.50 & $2.53 \pm 1.30$ & 0.69 & -0.84 & 51.38 & $1.17 \pm 0.65$ & 0.48 & -1.24 & 55.55 \\
\hline
\end{tabular}

Table 4

Reproductive effort in the Lythrum salicaria populations (in \%).

\begin{tabular}{|c|c|c|c|}
\hline Patch & $\bar{x} \pm \mathrm{SD}$ & $\min$. & $\max$. \\
\hline $\mathrm{A}$ & $14.20 \pm 8.13$ & 5.72 & 47.79 \\
\hline $\mathrm{B}$ & $15.14 \pm 5.00$ & 7.04 & 27.39 \\
\hline $\mathrm{C}$ & $14.82 \pm 3.28$ & 6.96 & 20.56 \\
\hline
\end{tabular}



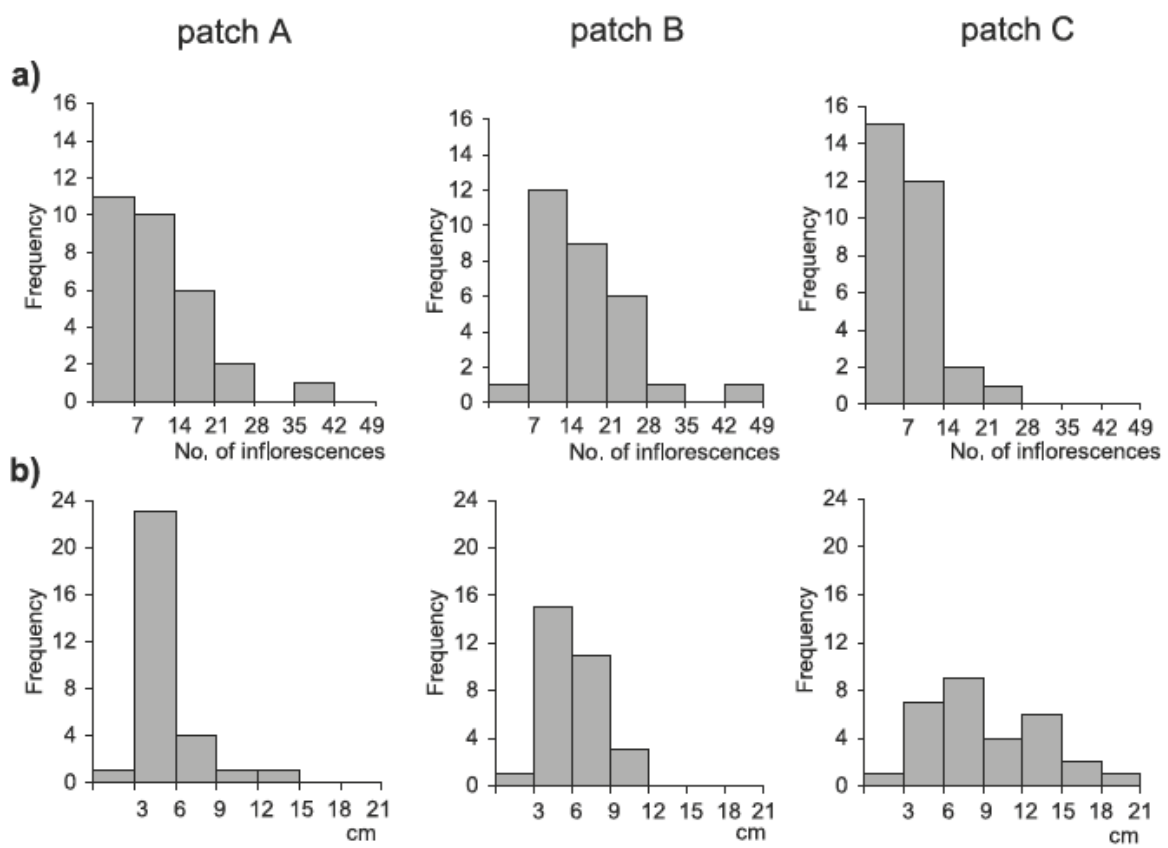

Fig. 1. Distribution of number of inflorescences (a) and inflorescence length (b) in 30 generative individuals in the Lythrum salicaria populations in patches $\mathrm{A}, \mathrm{B}$ and $\mathrm{C}$.
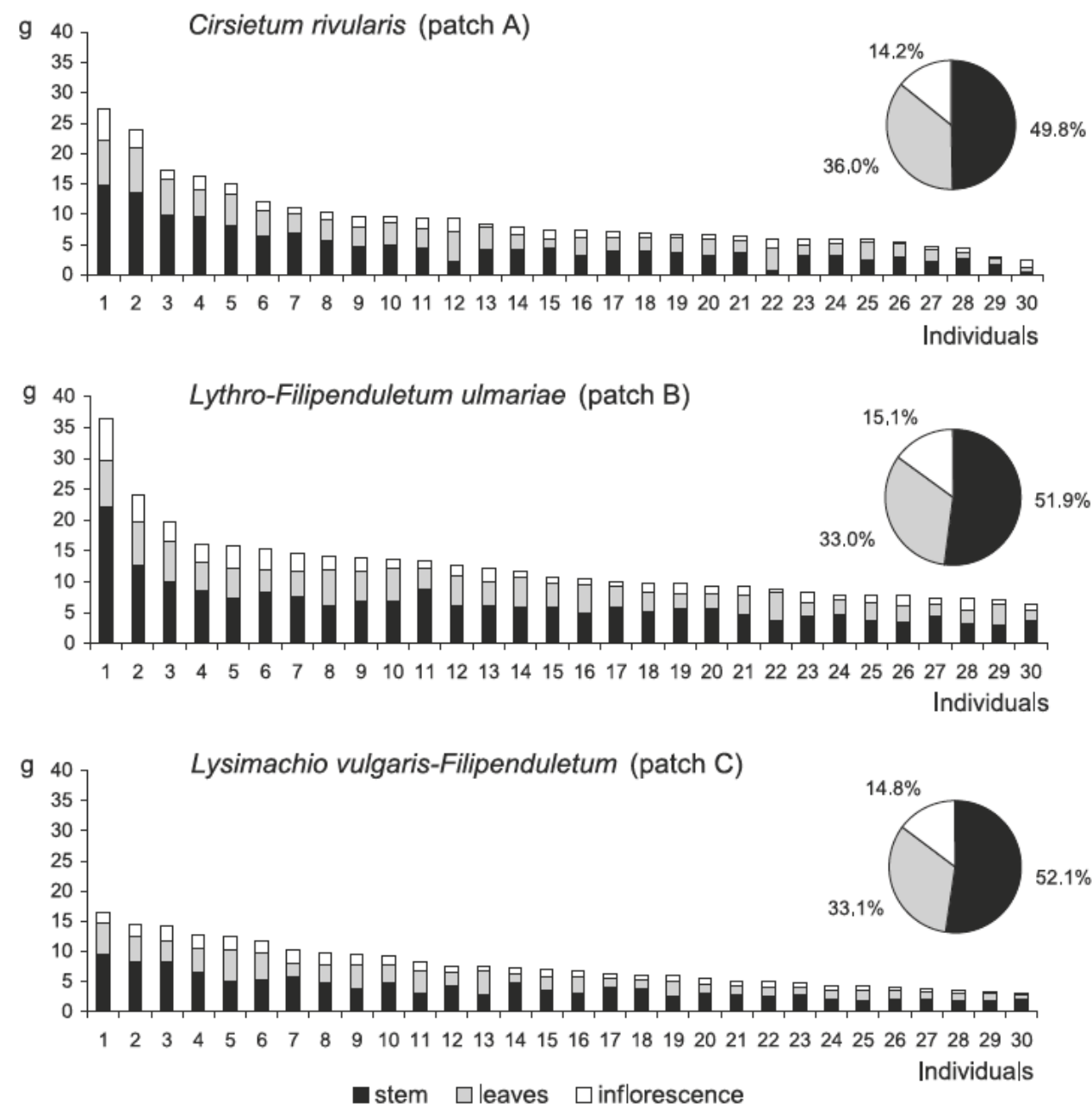

Fig. 2. Differentiation of the biomass allocation in 30 generative individuals in the Lythrum salicaria populations in patches A, B and C; cyclogram - the entire sample (in \%). 
density among all three analysed populations, the inflorescence biomass in this patch is greater by $52 \%$ and $66 \%$ than in the remaining patches of Cirsietum rivularis (patch A) and Lysimachio vulgaris-Filipenduletum (patch C), respectively. In patch $\mathrm{C}$, in turn, there occur individuals of the tallest stems. This fact is connected with the habitat conditions, that is, with considerable solum moisture and, first of all, with a dense and tall herb layer, which reinforces the interspecific competition, particularly on the part of Carex acutiformis. Additionally, the shading caused by the entering of willowalder shrubs makes the individuals of $L$. salicaria 'run to the sun' (F a l in s k a , 1990). Tall ramets raise inflorescences above the herbaceous layer also because of pollinators, especially the Lepidoptera. Yet, despite the fact that in the patch of Lysimachio vulgaris-Filipenduletum generative ramets are the tallest and inflorescences the longest, their size does not affect the reproductive effort in this population.

The percentage of biomass spent on reproduction is different not merely across the individuals of different species, but often among the plants of the same one (Harper, 1977). The reproductive effort may depend on genet age, size and sex, as well as on habitat conditions of a population, its density, the succession stage of a community, abundance of nutrient resources and light conditions, and on the influence of competition, although these relationships are not always unambiguous (Harper and Ogden, 1970; Gaines et al. 1974; van Andel and Vera, 1977; Newe 11, 1978; Samson and Werk, 1986; Werpachowski, 1989; P ow e ls on and Li effers, 1992; Verburg and Grava, 1998; Hemborg and Karlsson, 1999; P in o et al. 2002).

In the case of $L$. salicaria the reproductive effort measured by the participation of inflorescence biomass in the biomass of aboveground parts of genets, exhibits similar values (14.2-15.1\%) in all the study populations, despite their habitat conditions. This fact proves that at the population level, the reproductive effort is relatively stable. In L. salicaria populations the biomass percentage spent on reproduction is not connected with the number of generative ramets, produced by a genet, similarly to other populations occurring in hydrogenic habitats, e.g. Caltha palustris (We r pach ow s ki , 1989) and Senecio rivularis (C z a r n e c k a , 1995).

The study shows that, at the level of a whole population, different habitat conditions are not decisive for the differentiation of the matter and energy allocation pattern between vegetative and generative structures. However, particular genets in a population, depending on the habitat microstructure and the biotic relations with other individuals both of their own and other species, may realise their own reproductive strategies, being a part of their life strategies (H a r p e r, 1977; S o u t h w o o d, 1988; K o zło w s ki, 1992).

\section{REFERENCES}

Craw ley M. J., 1997. Life history and environment. [In:] Plant ecology. M.J. Crawley (ed.), Blackwell Sci. Publ., Oxford, pp. 73-131.

Czarnecka B ., 1995. Biology and ecology of the island populations of Senecio rivularis (Waldst. et Kit.) DC. and Senecio umbrosus Waldst. et Kit. Rozpr. Wydziału Biologii i Nauk o Ziemi. Rozpr. habil. 48, Wyd. UMCS, pp. 262 (in Polish with English summary).

Falińska K., 1990. Individual, population, phytocoenosis. PWN, Warszawa, pp. 310 (in Polish).

Falińska K., 1991. Succession as an effect of plant demographic processes. [In:] Vegetation and plant populations dynamics. J.B. Faliński (ed.), Phytocoenosis 3 (N.S.) Sem. Geobot. 1: 43-67 (in Polish with English summary).

F a lińs k a K., 2003. Alternative pathways of succession. Phytocoenosis (N.S.) 15, Archivum Geobotanicum, 9: 1-100.

Gaines M. S., Voght K. J., H a mrick J. L., 1974. Reproductive strategies and growth patterns in sunflowers (Helianthus). Am. Nat. 108: 889-893.

Harper J. L., 1977. Population biology of plants. Academic Press, London, pp. 892.

Harper J. L., Ogden J., 1970. The reproductive strategy of higher plants. The concept of strategy with special reference to Senecio vulgaris L. J. Ecol. 58: 681-698.

He mborg A. M., Karls s o n P. S., 1999. Sexual differences in biomass and nutrient allocation of first-year Silene dioica plants. Oecologia, 118: 453-460.

K o zło w s k i J., 1992. Optimal allocation of resources to growth and reproduction: implications for age and size at maturity. Trends Ecol. Evol. 7: 15-19.

Łuk a s i e w i c z A., 1962. Morfologiczno-rozwojowe typy bylin [Morphological-developmental types of perennials]. Prace Kom. Biol. PTPN, 27: 1- 398 (in Polish).

N ewe11 S. J., 1978. Reproductive strategies in herbaceous plant communities during succession. Ecology, 59: 228-234.

P in o J., S an s F. X., M as alles R. M., 2002. Size-dependent reproductive pattern and short-term reproductive cost in Rumex obtusifolius L. Acta Oecol. 23: 321-328.

P ow el s o n R. A., Li e ffe r s V. J., 1992. Effect of light and nutrients on biomass allocation in Calamagrostis canadensis. Ecography, 15: 31-36.

S a m s on D. A., Werk K. S., 1986. Size-dependent effects in the analysis of reproductive effort in plants. Am. Nat. 127: $667-680$.

Silvertown J. W., Lovett Doust J., 1993. Introduction to plant population biology. 3rd ed. Blackwell Science, Oxford, pp. 210.

Southwood T. R. E., 1988. Tactics, strategies and templets. Oikos 52: 3-18.

Stearns S. C., 1992. The evolution of life histories. Oxford Univ. Press., Oxford, pp. 249.

Van Andel J., Vera F., 1977. Reproductive allocation in Senecio sylvaticus and Chamaenerion angustissimum in relation to mineral nutrition. J. Ecol. 65: 747-758. 
Verburg R., Grava D., 1998. Differences in allocation patterns in clonal and sexual offspring in a woodland pseudo-annual. Oecologia, 115: 472-477.

Werpachowski C., 1989. Reproductive strategies of Caltha palustris L. under various living conditions. Acta Soc. Bot. Pol. 58: 423-437.

\section{Wysilek reprodukcyjny jako element strategii życiowej populacji Lythrum salicaria $\mathrm{L}$.}

\section{Streszczenie}

Celem badań było porównanie wybranych cech strategii życiowej osobników krwawnicy pospolitej Lythrum salicaria w trzech populacjach łąkowych, bytujących w zróżnicowanych warunkach siedliskowych. Poszukiwano odpowiedzi na następujące pytania: Czy odmienne warunki środowiskowe wpływaja na sposób podziału materii między poszczególne organy? Czy osobniki różnych populacji tego samego gatunku mogą realizować własną strategię reprodukcyjna, tzn., czy ich wysiłek reprodukcyjny może kształtować się na zróżnicowanym poziomie? U L. salicaria wysiłek reprodukcyjny mierzony udziałem biomasy kwiatostanów w biomasie części nadziemnych genetów przyjmuje zbliżone wartości $(14,2-15,1 \%)$ we wszystkich badanych populacjach, niezależnie od warunków środowiskowych. Dowodzi to, że wysiłek reprodukcyjny na poziomie populacji jest wartością względnie stałą. Natomiast poszczególne osobniki w każdej z badanych populacji, w zależności od mikrostruktury siedliska i oddziaływań biotycznych z innymi osobnikami własnego, jak i innych gatunków, mogą realizować własną strategię reprodukcyjną, będącą częścią ich strategii życiowej. 